\title{
COMPOSTING AND VERMICOMPOSTING USED TO BREAK DOWN AND REMOVE POLLUTANTS FROM ORGANIC WASTE: A MINI REVIEW
}

\author{
ALENA GRASSEROVÁ ${ }^{1,2}$, ALEŠ HANČ ${ }^{3}$, PETRA INNEMANOVÁ ${ }^{1,4}$, \\ and TOMÁŠ CAJTHAML ${ }^{1,2, *}$

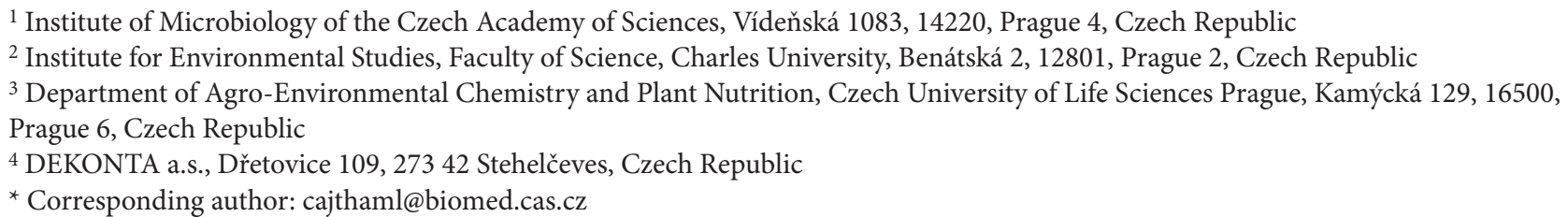

\section{ABSTRACT}

The advantages of combining composting and vermicomposting to break down and remove pollutants from organic waste are reviewed. This mini-review aims to present the benefits of combining these methods and the outcome of specific cases of environmental remediation.

Keywords: composting; earthworms; heavy metals; organic pollutants; sewage sludge

\section{Introduction}

Organic substances occur in nature due to human activities and natural processes (Luo et al. 2014). These compounds occur throughout the environment at low trace concentrations; nevertheless, their negative effects on organisms including humans are well known. Such organic substances include pesticides, pharmaceuticals, personal care products, endocrine disruptors and industrial chemicals. Organic contaminants and heavy metals are not completely removed by wastewater treatment plants (WWTPs). The by-product, WWTP sludge, is rich in nutrients and therefore used as an agricultural fertilizer (Clarke and Smith 2011). In order to remove micropollutants from bio solids and at the same time maintain their valuable properties, green technologies called bioremediations are being developed (Hickman and Reid 2008). Typical biotechnologies for this purpose are composting or vermicomposting, which are environmentally friendly, low-maintenance and low-cost methods. When these two processes are combined, even better outcomes can be achieved in terms of breaking down organic matter and removal of pollutants from bio solids (Lim et al. 2016). The objective of this paper is to review the advantages of combining composting and vermicomposting in terms of both the properties of the end product and removal of pollutants.

\section{Composting}

During thermogenic composting, the organic matter is decomposed by microorganisms (Finstein and Morris 1975), so it is important to aerate the compost, in order to replenish the oxygen. Under optimal conditions, the thermal phase takes around one month (de Bertoldi et al. 1983). The main decomposers are bacteria, fungi, actinomycetes or protozoa. Over many years, composting has also been used for the bioremediation of polluted substrates (Cajthaml et al. 2002; Cai et al. 2007; Covino et al. 2016; Iranzo et al. 2018; Guo et al. 2020; Wei et al. 2020).

\section{Vermicomposting}

Vermicomposting is a process in which earthworms are used to break down organic matter (Domínguez 2004). The decomposition starts in the gizzards of the earthworms' after which the organic matter is digested by enzymes and microorganism in their guts. Product of vermicomposting is rich in nutrients and can be re-used as organic fertilizer (Yadav and Garg 2019). If a pollutant is removed from the soil via vermicomposting, the process is called vermiremediation (Rodriguez-Campos et al. 2014). Shi et al. (2019) recently defined vermiremediation as "an earthworm-based bioremediation technology that makes use of the earthworm's life cycle (i.e., feeding, burrowing, metabolism, secretion) or their interaction with other abiotic and biotic factors to accumulate and extract, transform, or degrade contaminants in the soil environment". Processes involved in vermiremediation are vermiaccumulation, vermiextraction, vermitransformation and drilodegradation (Shi et al. 2019). Earthworms can successfully remove organic micropollutants (Chachina et al. 2016; Chevillot et al. 2017; Havranek et al. 2017; Rorat et al. 2017; Lin et al. 2019; Owagboriaye et al. 2020) and heavy metals (Azizi et al. 2013a; Suthar et al. 2014; He et al. 2016). 


\section{Combination of composting and vermicomposting used to break down organic waste}

Composting and vermicomposting alone are very successful methods for decomposing organic waste. However, each has its drawbacks, which can be overcome by combining the two techniques (Lim et al. 2016). Temperatures during self-heating of the compost can increase to $80{ }^{\circ} \mathrm{C}$ (Finstein and Morris 1975). These elevated temperatures (higher than $55^{\circ} \mathrm{C}$ ) are necessary to suppress pathogens in sludge (Grewal et al. 2006) but at the same time are lethal for earthworms (Domínguez 2004). It is therefore reasonable to start with composting, during which the pathogens are killed and the decomposition process begins. Ndegwa and Thompson (2001) confirm that by combining composting-vermicomposting eliminates pathogens. On the contrary, starting with vermicomposting, followed by composting, results in that the system does not reach temperatures high enough to kill the pathogens.

When the thermophilic phase is completed, earthworms are added to continue the decomposition and facilitate aeration of the material. The earthworms disturb the organic material and produce very small particles with favourable agrochemical properties resulting in high concentrations of available nitrogen and phosphorus (Hanc and Dreslova 2016). The size of the particles is crucial, as small particles have a large total surface area, which makes it easier for the microbes to access the material. Tognetti et al. (2005) report another benefit of the composting-vermicomposting method. As mentioned above, the thermophilic phase is detrimental to earthworms, therefore large areas are needed for spreading the material to prevent overheating. However, if the waste is subjected to the thermophilic phase prior to vermicomposting, the latter can be initiated in the surface layer, which reduces the demands on space. The same authors report a difference between compost and pre-composted vermicompost in terms of nutrient content. The pre-composted vermicompost has higher nutrient concentrations and an enhanced microbial activity resulting in a higher yield of ryegrass when applied as a fertiliser. However, these authors also point out that the quality of the product is not only dependent on the technology used, but also on the starting material, that is, the nature of the waste and bulking agent.

Table 1 gives examples of composting-vermicomposting using different kinds of organic waste. It is apparent that the incubation time for composting and vermicomposting is not the same. Composting usually takes around two to four weeks depending on the starting material and duration of the thermophilic phase. For instance, Nair et al. (2006) suggest for producing pathogen free compost from kitchen waste 9 days of pre-composting followed by 2.5 months of vermicomposting. Thermocomposting reduces both the time and area needed for vermicomposting by reducing the volume of material to be processed.

\section{Composting-vermicomposting used to remove pollutants}

Earthworms can accumulate heavy metals and organic pollutants (Sinha et al. 2008). Moreover, they increase their availability for microorganisms by grinding the waste into smaller particles. Earthworms generally improve soil microbial activity by stimulating the growth of bacteria and fungi both in their intestine and their faeces (Dendooven et al. 2011). Increase in activity of the detoxification enzymes cytochrome P450 and glutathione-S-transferase in earthworms are reported when they ingest different kinds of pollutants, which indicates earthworms are also able to degrade pollutants (Achazi et al. 1998; Zhang et al. 2009; Zhao et al. 2020). Earthworms are great accumulators of metals, especially zinc and cadmium, which are incorporated into their soft tissues. In that sense, earthworms can also act as indicators of metal pollution. Metals can also be transformed to a valent state inside earthworms, which makes them more available for plants.

Pollutants are not always completely removed from WWTP (Luo et al. 2014), in which case the WWTP sludge should not be used as a fertiliser, as it would contaminate field plants and the whole food chain. Composting and vermicomposting are both proven to be successful methods for removing pollutants (Poulsen and Bester 2010). However, vermicomposting is not suitable for the immediate remediation of WWTP sewage sludge due to the toxicity of $\mathrm{NH}_{3}$ and $\mathrm{CH}_{4}$ (Awiszus et al. 2018). Pre-composting with a nutrient-rich bulking agent, such as cow manure or green waste, stabilizes sewage sludge (Kaushik and Garg 2003; Hanc and Dreslova 2016). It not only reduces its toxicity to earthworms, but also adds nutrients to the final product.

Vermiremediation of sewage sludge or contaminated soil using pre-composting has been investigated (see Table 2). However, there is no detailed comparison of pre-composting-vermicomposting with composting and vermicomposting in terms of pollutant removal. Composting followed by vermiremediation is studied mainly for its efficiency in removing heavy metals and polycyclic aromatic hydrocarbons. Maňáková et al. (2014) report that combining these processes results in a greater reduction in the mobility and bioavailability of arsenic. The mobile arsenic pool is reduced to $4 / 9$ of its initial value due to bioaccumulation. Soobhany et al. (2015) confirm the vermiaccumulation of other heavy metals with decrease in the bioaccumulation factors (BCFs) as follows: $\mathrm{Cd}>\mathrm{Ni}>\mathrm{Cu}>\mathrm{Co}>\mathrm{Cr}>\mathrm{Zn}$. In contrast, composting without earthworms results in a progressive increase in heavy metal concentrations due to the reduction in the volume of compost due to decomposition. Rorat et al. 
Table 1 Summary of the results of composting-vermicomposting of organic wastes.

\begin{tabular}{|c|c|c|c|c|c|c|}
\hline Organic waste & $\begin{array}{l}\text { Bulking agent } \\
\text { (amendment) }\end{array}$ & $\begin{array}{c}\text { Composting } \\
\text { duration } \\
\text { (days) }\end{array}$ & $\begin{array}{l}\text { Vermicom- } \\
\text { posting } \\
\text { duration } \\
\text { (days) }\end{array}$ & $\begin{array}{l}\text { Earthworms } \\
\text { used }\end{array}$ & Notes/Findings & Reference \\
\hline $\begin{array}{l}\text { Municipal } \\
\text { sewage sludge } \\
\text { digestate }\end{array}$ & $\begin{array}{l}\text { Green waste, spent } \\
\text { mushroom compost, } \\
\text { wheat straw, biochar }\end{array}$ & 43 & 90 & Eisenia fetida & $\begin{array}{l}\text { Similar outcomes as conventional } \\
\text { composting, but kinetin concen- } \\
\text { tration was two times higher. }\end{array}$ & Rékási et al. 2019 \\
\hline Vinasse & $\begin{array}{l}\text { Bagasse, cow ma- } \\
\text { nure, zeolite }\end{array}$ & 21 & 60 & Eisenia fetida & $\begin{array}{l}\text { Lower content of vinasse and } \\
\text { higher content of zeolite resulted } \\
\text { in better quality compost. }\end{array}$ & Alavi et al. 2017 \\
\hline Sewage sludge & $\begin{array}{l}\text { Municipal solid } \\
\text { waste, grass } \\
\text { clippings, sawdust }\end{array}$ & 30 & 45 & $\begin{array}{l}\text { Eisenia andrei, } \\
\text { Eisenia fetida, } \\
\text { Dendrobaena } \\
\text { veneta }\end{array}$ & $\begin{array}{c}\text { Eisenia species of earthworms } \\
\text { exhibited stronger defence and } \\
\text { higher ability to accumulate } \\
\text { heavy metals. }\end{array}$ & $\begin{array}{l}\text { Suleiman et al. } \\
2017\end{array}$ \\
\hline Press mud & $\begin{array}{l}\text { Cow dung, green } \\
\text { manure plants }\end{array}$ & 21 & 50 & Eudrilus eugeniae & $\begin{array}{l}\text { Ratio 2:1:1 (pressmud : cow } \\
\text { dung : green manure plants) } \\
\text { resulted in the high quality } \\
\text { compost. }\end{array}$ & $\begin{array}{c}\text { Balachandar et al. } \\
2020\end{array}$ \\
\hline Garden waste & $\begin{array}{l}\text { Cattle manure, spent } \\
\text { mushroom substrate }\end{array}$ & 21 & 70 & Eisenia fetida & $\begin{array}{c}\text { Ratio 2:1:1 (garden waste : cattle } \\
\text { manure : spent mushroom } \\
\text { substrate) resulted in high quality } \\
\text { compost. }\end{array}$ & Gong et al. 2019 \\
\hline Pistachio waste & Cow dung & 45 & 45 & Eisenia fetida & $\begin{array}{c}\text { Ratio 1:3 (pistachio waste : cow } \\
\text { dung) resulted in high quality } \\
\text { compost. }\end{array}$ & $\begin{array}{l}\text { Esmaeili et al. } \\
\qquad 2020\end{array}$ \\
\hline Vegetable waste & $\begin{array}{c}\text { Cow dung, saw dust, } \\
\text { dried leaves }\end{array}$ & 8 & 20 & $\begin{array}{c}\text { Eisenia fetida, } \\
\text { Eudrilus eugeniae }\end{array}$ & $\begin{array}{l}\text { Stabilized end product within } \\
\text { a short period of time using } \\
\text { rotary drum. }\end{array}$ & $\begin{array}{c}\text { Varma } \\
\text { and Kalamdhad } \\
2016\end{array}$ \\
\hline $\begin{array}{l}\text { Sugarcane } \\
\text { press mud }\end{array}$ & $\begin{array}{c}\text { Bagasse, sugarcane } \\
\text { trash }\end{array}$ & 30 & 40 & Drawida willsi & $\begin{array}{l}\text { Composting-vermicompost- } \\
\text { ing method reduced the time } \\
\text { required for composting. }\end{array}$ & Kumar et al. 2010 \\
\hline $\begin{array}{l}\text { Rice straw, } \\
\text { paper waste }\end{array}$ & Cow dung & 21 & 105 & Eisenia fetida & $\begin{array}{l}\text { High fragmentation and homoge- } \\
\text { neity of vermicompost based on } \\
\text { SEM pictures. }\end{array}$ & $\begin{array}{c}\text { Sharma } \\
\text { and Garg } 2018\end{array}$ \\
\hline $\begin{array}{l}\text { Press mud } \\
\text { sludge }\end{array}$ & Cattle dung & 15 & 135 & Eisenia fetida & $\begin{array}{l}\text { Ratio 1:3 (compressed sludge : cat- } \\
\text { tle dung) resulted in good growth } \\
\text { and fecundity of earthworms. }\end{array}$ & Bhat et al. 2016 \\
\hline $\begin{array}{l}\text { Sewage sludge, } \\
\text { vinasse }\end{array}$ & Rabbit manure & 21 & 56 & Eisenia fetida & $\begin{array}{l}\text { Rabbit manure enhanced the } \\
\text { reproduction and weight of } \\
\text { earthworms. }\end{array}$ & Molina et al. 2013 \\
\hline $\begin{array}{l}\text { Tomato crop } \\
\text { residues }\end{array}$ & Almond shells & 63 & 198 & $\begin{array}{l}\text { Eisenia andrei, } \\
\text { Eisenia fetida }\end{array}$ & $\begin{array}{l}\text { Vermicompost and } \\
\text { pre-composted vermicompost } \\
\text { had similar properties. }\end{array}$ & Fornes et al. 2012 \\
\hline
\end{tabular}

(2017) also report vermiaccumulation of heavy metals, with decreases in BCFs as follows: $\mathrm{Cd}>\mathrm{Cu}>\mathrm{Zn}>\mathrm{Ni}$ $>\mathrm{Cr}>\mathrm{Pb}$. Kharrazi et al. (2014), on the other hand, report increases in heavy metals concentrations in compost produced by the composting-vermicomposting process. These authors discuss possible reasons for this e.g. mineralization making metals more available or loss of the overall mass due to decomposition. They did not study the vermiaccumulation of heavy metals. Suleiman et al. (2017) report the accumulation of heavy metals by three species of earthworm, namely Eisenia andrei, Eisenia fetida and Dendrobaena veneta. BCFs were ranked as follows: $\mathrm{Cd}>\mathrm{Co}>\mathrm{Cu}>\mathrm{Zn}>\mathrm{Ni}>\mathrm{Pb}>\mathrm{Cr}$. Of the earthworms studied, the Eisenia species exhibit the highest ability to vermiaccumulate heavy metals.
The fate of polycyclic aromatic hydrocarbons (PAHs) during vermicomposting is also reported. Rorat et al. (2017) report a significant reduction in 16 priority PAHs after 30 days of composting followed by 35 days of vermicomposting. Total amount of PAHs is reduced by up to $85.75 \%$, with the reduction in naphthalene, acenaphtylene, phenanthrene and benzo(g,h,i)perylene the most marked. In addition to vermiaccumulation, degradation is reported, namely that of 5-rings PAHs to 3and 4-rings PAHs. Composting alone is efficient when degrading PAHs (Cajthaml and Šašek 2005). However, degradation occurs in the final maturation phase, which can take up to 300 days. Composting-vermicomposting could therefore potentially decrease the time required to remove PAHs. 
Table 2 Summary of the results of pre-composting followed by vermiremediation of pollutants.

\begin{tabular}{|c|c|c|c|c|c|c|c|}
\hline Pollutant & Matrix & $\begin{array}{l}\text { Bulking agent } \\
\text { (amendment) }\end{array}$ & $\begin{array}{l}\text { Composting } \\
\text { duration } \\
\text { (days) }\end{array}$ & $\begin{array}{l}\text { Vermicom- } \\
\text { posting } \\
\text { duration } \\
\text { (days) }\end{array}$ & $\begin{array}{l}\text { Earthworms } \\
\text { used }\end{array}$ & Notes/Findings & Reference \\
\hline Arsenic & $\begin{array}{l}\text { Sewage } \\
\text { sludge }\end{array}$ & $\begin{array}{l}\text { Horse manure, sawdust, } \\
\text { grass clippings }\end{array}$ & 90 & 90 & Eisenia fetida & $\begin{array}{l}\text { Decrease in mobility } \\
\text { to } 4 / 9 .\end{array}$ & $\begin{array}{c}\text { Maňáková et al. } \\
2014\end{array}$ \\
\hline Heavy metals & $\begin{array}{l}\text { Municipal } \\
\text { solid waste }\end{array}$ & $\begin{array}{c}\text { Food waste, paper waste, } \\
\text { yard waste, cow dung }\end{array}$ & 17 & 53 & $\begin{array}{l}\text { Eudrilus } \\
\text { eugeniae }\end{array}$ & $\begin{array}{c}\text { BCFs: } \mathrm{Cd}>\mathrm{Ni}>\mathrm{Cu}> \\
\mathrm{Co}>\mathrm{Cr}>\mathrm{Zn} .\end{array}$ & $\begin{array}{c}\text { Soobhany et al. } \\
2015\end{array}$ \\
\hline Heavy metals & $\begin{array}{l}\text { Sewage } \\
\text { sludge }\end{array}$ & $\begin{array}{l}\text { Miscanthus green waste, } \\
\text { market waste, organic } \\
\text { fraction of municipal } \\
\text { solid waste }\end{array}$ & 30 & 35 & Eisenia andrei & $\begin{array}{c}\text { BCFs: } \mathrm{Cd}>\mathrm{Cu}>\mathrm{Zn}> \\
\mathrm{Ni}>\mathrm{Cr}>\mathrm{Pb} .\end{array}$ & $\begin{array}{l}\text { Rorat et al. } \\
\quad 2017\end{array}$ \\
\hline Heavy metals & $\begin{array}{l}\text { Sewage } \\
\text { sludge }\end{array}$ & $\begin{array}{l}\text { Corn waste, cow dung, } \\
\text { compost, paper }\end{array}$ & 30 & 40 & Eisenia fetida & $\begin{array}{c}\text { Increase in heavy } \\
\text { metal content due to } \\
\text { the decrease in overall } \\
\text { mass. }\end{array}$ & $\begin{array}{c}\text { Kharrazi et al. } \\
2014\end{array}$ \\
\hline Heavy metals & Pig manure & Rice straw & 15 & 45 & Eisenia fetida & $\begin{array}{l}\text { Increase in the } \mathrm{Cu} \text { and } \\
\mathrm{Zn} \text { availability after } \\
\text { vermicomposting. }\end{array}$ & Zhu et al. 2014 \\
\hline Heavy metals & $\begin{array}{l}\text { Sewage } \\
\text { sludge }\end{array}$ & $\begin{array}{l}\text { Spent mushroom } \\
\text { compost }\end{array}$ & 21 & 105 & $\begin{array}{l}\text { Lumbricus } \\
\text { rubellus }\end{array}$ & $\begin{array}{l}\text { 90-98.7\% removal of } \\
\mathrm{Cr}, \mathrm{Cd} \text { and } \mathrm{Pb} \text {. }\end{array}$ & $\begin{array}{l}\text { Azizi et al. } \\
2013 a\end{array}$ \\
\hline Heavy metals & $\begin{array}{l}\text { Sewage } \\
\text { sludge }\end{array}$ & $\begin{array}{l}\text { Municipal solid wastes, } \\
\text { grass clippings, sawdust }\end{array}$ & 30 & 45 & $\begin{array}{c}\text { Eisenia andrei, } \\
\text { Eisenia fetida, } \\
\text { Dendrobaena } \\
\text { veneta }\end{array}$ & $\begin{array}{c}\text { BCFs: } \mathrm{Cd}>\mathrm{Co}>\mathrm{Cu}> \\
\mathrm{Zn}>\mathrm{Ni}>\mathrm{Pb}>\mathrm{Cr} .\end{array}$ & $\begin{array}{c}\text { Suleiman et al. } \\
2017\end{array}$ \\
\hline $\begin{array}{l}\text { Petroleum } \\
\text { hydrocarbons }\end{array}$ & Soil & Compost & $\begin{array}{l}\mathrm{x} \text { (compost as } \\
\text { amendment) }\end{array}$ & 15 & Eisenia fetida & \begin{tabular}{|c} 
Enrichment of \\
microorganisms after \\
adding compost as an \\
amendment.
\end{tabular} & $\begin{array}{c}\text { Ceccanti et al. } \\
2006\end{array}$ \\
\hline 16 priority PAHs & $\begin{array}{l}\text { Sewage } \\
\text { sludge }\end{array}$ & $\begin{array}{c}\text { Miscanthus green waste, } \\
\text { markets waste, organic } \\
\text { fraction of municipal } \\
\text { solid waste }\end{array}$ & 30 & 35 & Eisenia andrei & $\begin{array}{l}\text { Degradation of 5-ring } \\
\text { PAHs to 3- and 4-ring } \\
\text { PAHs is reported. }\end{array}$ & $\begin{array}{l}\text { Rorat et al. } \\
\quad 2017\end{array}$ \\
\hline $\begin{array}{l}\text { Anthracene, } \\
\text { phenanthrene, } \\
\text { benzo(a)pyrene }\end{array}$ & $\begin{array}{l}\text { Soil, sewage } \\
\text { sludge }\end{array}$ & $x$ & 21 & 60 & $\begin{array}{l}\text { Lumbricus } \\
\text { rubellus }\end{array}$ & 99.99\% PAHs removed. & $\begin{array}{l}\text { Azizi et al. } \\
2013 b\end{array}$ \\
\hline Asphaltenes & $\begin{array}{l}\text { Heavy } \\
\text { fuel oil }\end{array}$ & $\begin{array}{l}\text { Cow bedding, rice husks, } \\
\text { seaweed extracts, potato } \\
\text { peelings }\end{array}$ & 112 & 183 & Eisenia fetida & $\begin{array}{c}\text { Microorganisms } \\
\text { obtained carbon } \\
\text { and energy from } \\
\text { asphaltenes. }\end{array}$ & $\begin{array}{c}\text { Martín-Gil et al. } \\
2008\end{array}$ \\
\hline
\end{tabular}

\section{Conclusion}

Pre-composting is an important step when decomposing organic waste by vermicomposting. It facilitates its breakdown, suppresses pathogens and decomposes toxic compounds, which could harm the earthworms. Moreover, as it results in a reduction in mass, less time and space is needed for vermicomposting. Pre-composting can be also used prior to the vermiremediation of WWTPs sludge and contaminated soil. A combination of composting and vermicomposting has been successfully used for removing polycyclic aromatic hydrocarbons and heavy metals. However, no research has been done on using this method for removing other organic pollutants, such as pharmaceuticals or endocrine disruptors. This mini-review indicates that composting-vermicomposting is a promising low-cost and environmentally friendly way of treating contaminated WWTP sludge.

\section{Acknowledgements}

This work was supported by The Ministry of Agriculture of the Czech Republic (grant number QK1910095).

\section{REFERENCES}

Achazi RK, Flenner C, Livingstone DR, Peters LD, Schaub K, Scheiwe E (1998) Cytochrome P450 and dependent activities in unexposed and PAH-exposed terrestrial annelids. Comp Biochem Physiol C Pharmacol Toxicol Endocrinol 121:339-350.

Alavi N, Daneshpajou M, Shirmardi M, Goudarzi G, Neisi A, Babaei AA (2017) Investigating the efficiency of co-composting and vermicomposting of vinasse with the mixture of cow manure wastes, bagasse, and natural zeolite. Waste Manag 69: 117-126.

Awiszus S, Meissner K, Reyer S, Müller J (2018) Ammonia and methane emissions during drying of dewatered biogas digestate in a two-belt conveyor dryer. Bioresour Technol 247: 419-425. 
Azizi AB, Lim MPM, Noor ZM, Abdullah N (2013a) Vermiremoval of heavy metal in sewage sludge by utilising Lumbricus rubellus. Ecotoxicol Environ Saf 90: 13-20.

Azizi AB, Liew KY, Noor ZM, Abdullah N (2013b) Vermiremediation and mycoremediation of polycyclic aromatic hydrocarbons in soil and sewage sludge mixture: a comparative study. Int J Environ Sci Dev 4: 565-568.

Balachandar R, Baskaran L, Yuvaraj A, Thangaraj R, Subbaiya R, Ravindran B, Chang SW, Karmegam N (2020) Enriched pressmud vermicompost production with green manure plants using Eudrilus eugeniae. Bioresour Technol 299: 122578.

Bhat SA, Singh J, Vig AP (2016) Effect on growth of earthworm and chemical parameters during vermicomposting of pressmud sludge mixed with cattle dung mixture. Procedia Environ Sci 35: 425-434.

Cai Q-Y, Mo C-H, Wu Q-T, Zeng Q-Y, Katsoyiannis A, Ferard J-F (2007) Bioremediation of polycyclic aromatic hydrocarbons (PAHs)-contaminated sewage sludge by different composting processes. J Hazard Mater 142: 535-542.

Cajthaml T, Bhatt M, Šašek V, Matějů V (2002) Bioremediation of PAH-contaminated soil by composting: A case study. Folia Microbiol 47: 696-700.

Cajthaml T, Šašek V (2005) Application of supercritical fluid extraction (SFE) to predict bioremediation efficacy of longterm composting of PAH-contaminated soil. Environ Sci Technol 39: 8448-8452.

Ceccanti B, Masciandaro G, Garcia C, Macci C, Doni S (2006) Soil bioremediation: combination of earthworms and compost for the ecological remediation of a hydrocarbon polluted soil. Water Air Soil Pollut 177: 383-397.

Chachina SB, Voronkova NA, Baklanova ON (2016) Biological remediation of the petroleum and diesel contaminated soil with earthworms Eisenia fetida. Procedia Eng 152: 122-133.

Chevillot F, Convert Y, Desrosiers M, Cadoret N, Veilleux É, Cabana H, Bellenger JP (2017) Selective bioaccumulation of neonicotinoids and sub-lethal effects in the earthworm Eisenia andrei exposed to environmental concentrations in an artificial soil. Chemosphere 186: 839-847.

Clarke BO, Smith SR (2011) Review of 'emerging' organic contaminants in biosolids and assessment of international research priorities for the agricultural use of biosolids. Environ Int 37: 226-247.

Covino S, Fabianová T, Křesinová Z, Čvančarová M, Burianová E, Filipová A, Vořísková J, Baldrian P, Cajthaml T (2016) Polycyclic aromatic hydrocarbons degradation and microbial community shifts during co-composting of creosote-treated wood. J Hazard Mater 301: 17-26.

de Bertoldi M, Vallini G, Pera A (1983) The biology of composting: A review. Waste Manag Res 1: 157-176.

Dendooven L, Alvarez-Bernal D, Contreras-Ramos SM (2011) Earthworms, a means to accelerate removal of hydrocarbons (PAHs) from soil? A mini-review. Pedobiologia 54: 187-192.

Domínguez J (2004) State-of-the-art and new perspectives on vermicomposting research. In: Earthworm Ecology (2nd Edition). CRC Press, USA, pp 401-424.

Esmaeili A, Khoram MR, Gholami M, Eslami H (2020) Pistachio waste management using combined composting-vermicomposting technique: physico-chemical changes and worm growth analysis. J Clean Prod 242: 118523.

Finstein MS, Morris ML (1975) Microbiology of municipal solid waste composting. Adv Appl Microbiol 19: 113-151.

Fornes F, Mendoza-Hernández D, García-de-la-Fuente R, Abad M, Belda RM (2012) Composting versus vermicomposting: a comparative study of organic matter evolution through straight and combined processes. Bioresour Technol 118: 296-305.
Gong X, Li S, Carson MA, Chang SX, Wu Q, Wang L, An Z, Sun $X$ (2019) Spent mushroom substrate and cattle manure amendments enhance the transformation of garden waste into vermicomposts using the earthworm Eisenia fetida. J Environ Manage 248: 109263.

Grewal SK, Rajeev S, Sreevatsan S, Michel FC (2006) Persistence of Mycobacterium avium subsp. paratuberculosis and other zoonotic pathogens during simulated composting, manure packing, and liquid storage of dairy manure. Appl Env Microbiol 72: 565-574.

Guo Y, Rene ER, Wang J, Ma W (2020) Biodegradation of polyaromatic hydrocarbons and the influence of environmental factors during the co-composting of sewage sludge and green forest waste. Bioresour Technol 297: 122434.

Hanc A, Dreslova M (2016) Effect of composting and vermicomposting on properties of particle size fractions. Bioresour Technol 217: 186-189.

Havranek I, Coutris C, Norli HR, Rivier PA, Joner EJ (2017) Uptake and elimination kinetics of the biocide triclosan and the synthetic musks galaxolide and tonalide in the earthworm Dendrobaena veneta when exposed to sewage sludge. Environ Toxicol Chem 36: 2068-2073.

He X, Zhang Y, Shen M, Zeng G, Zhou M, Li M (2016) Effect of vermicomposting on concentration and speciation of heavy metals in sewage sludge with additive materials. Bioresour Technol 218: 867-873.

Hickman ZA, Reid BJ (2008) Earthworm assisted bioremediation of organic contaminants. Environ Int 34: 1072-1081.

Iranzo M, Gamón M, Boluda R, Mormeneo S (2018) Analysis of pharmaceutical biodegradation of WWTP sludge using composting and identification of certain microorganisms involved in the process. Sci Total Environ 640-641: 840-848.

Kaushik P, Garg VK (2003) Vermicomposting of mixed solid textile mill sludge and cow dung with the epigeic earthworm Eisenia foetida. Bioresour Technol 90: 311-316.

Kharrazi SM, Younesi H, Abedini-Torghabeh J (2014) Microbial biodegradation of waste materials for nutrients enrichment and heavy metals removal: An integrated composting-vermicomposting process. Int Biodeterior Biodegrad 92: 41-48.

Kumar R, Verma D, Singh BL, Kumar U (2010) Composting of sugar-cane waste by-products through treatment with microorganisms and subsequent vermicomposting. Bioresour Technol 101: 6707-6711.

Lim SL, Lee LH, Wu TY (2016) Sustainability of using composting and vermicomposting technologies for organic solid waste biotransformation: recent overview, greenhouse gases emissions and economic analysis. J Clean Prod 111: 262-278.

Lin Z, Zhen Z, Liang Y, Li J, Yang J, Zhong L, Zhao L, Li Y, Luo C, Ren L (2019) Changes in atrazine speciation and the degradation pathway in red soil during the vermiremediation process. J Hazard Mater 364: 710-719.

Luo Y, Guo W, Ngo HH, Nghiem LD, Hai FI, Zhang J, Liang S, Wang XC (2014) A review on the occurrence of micropollutants in the aquatic environment and their fate and removal during wastewater treatment. Sci Total Environ 473: 619-641.

Maňáková B, Kotyza J, Svobodová M, Hofman J (2014) Effects of combined composting and vermicomposting of waste sludge on arsenic fate and bioavailability. J Hazard Mater 280: 544-551.

Martín-Gil J, Navas-Gracia LM, Gómez-Sobrino E, Correa-Guimaraes A, Hernández-Navarro S, Sánchez-Báscones $M$, Ramos-Sánchez MdC (2008) Composting and vermicomposting experiences in the treatment and bioconversion of asphaltens from the Prestige oil spill. Bioresour Technol 99: $1821-1829$. 
Molina MJ, Soriano MD, Ingelmo F, Llinares J (2013) Stabilisation of sewage sludge and vinasse bio-wastes by vermicomposting with rabbit manure using Eisenia fetida. Bioresour Technol 137: 88-97.

Nair J, Sekiozoic V, Anda M (2006) Effect of pre-composting on vermicomposting of kitchen waste. Bioresour Technol 97: 2091-2095.

Ndegwa PM, Thompson SA (2001) Integrating composting and vermicomposting in the treatment and bioconversion of biosolids. Bioresour Technol 76: 107-112.

Owagboriaye F, Dedeke G, Bamidele J, Aladesida A, Isibor P, Feyisola R, Adeleke M (2020) Biochemical response and vermiremediation assessment of three earthworm species (Alma millsoni, Eudrilus eugeniae and Libyodrilus violaceus) in soil contaminated with a glyphosate-based herbicide. Ecol Indic 108: 105678 .

Poulsen TG, Bester K (2010) Organic micropollutant degradation in sewage sludge during composting under thermophilic conditions. Environ Sci Technol 44: 5086-5091.

Rékási M, Mazsu N, Draskovits E, Bernhardt B, Szabó A, Rivier P-A, Farkas C, Borsányi B, Pirkó B, Molnár S (2019) Comparing the agrochemical properties of compost and vermicomposts produced from municipal sewage sludge digestate. Bioresour Technol 291: 121861.

Rodriguez-Campos J, Dendooven L, Alvarez-Bernal D, Contreras-Ramos SM (2014) Potential of earthworms to accelerate removal of organic contaminants from soil: A review. Appl Soil Ecol 79: 10-25.

Rorat A, Wloka D, Grobelak A, Grosser A, Sosnecka A, Milczarek M, Jelonek P, Vandenbulcke F, Kacprzak M (2017) Vermiremediation of polycyclic aromatic hydrocarbons and heavy metals in sewage sludge composting process. J Environ Manage 187: 347-353.

Sharma K, Garg VK (2018) Comparative analysis of vermicompost quality produced from rice straw and paper waste employing earthworm Eisenia fetida (Sav.). Bioresour Technol 250: 708-715.

Shi Z, Liu J, Tang Z, Zhao Y, Wang C (2019) Vermiremediation of organically contaminated soils: Concepts, current status, and future perspectives. Appl Soil Ecol 147: 103377.

Sinha RK, Bharambe G, Ryan D (2008) Converting wasteland into wonderland by earthworms - a low-cost nature's technology for soil remediation: a case study of vermiremediation of PAHs contaminated soil. Environmentalist 28: 466-475.

Soobhany N, Mohee R, Garg VK (2015) Comparative assessment of heavy metals content during the composting and vermicomposting of municipal solid waste employing Eudrilus eugeniae. Waste Manag 39: 130-145.

Suleiman H, Rorat A, Grobelak A, Grosser A, Milczarek M, Płytycz, B, Kacprzak M, Vandenbulcke F (2017) Determination of the performance of vermicomposting process applied to sewage sludge by monitoring of the compost quality and immune responses in three earthworm species: Eisenia fetida, Eisenia andrei and Dendrobaena veneta. Bioresour Technol 241: 103-112.

Suthar S, Sajwan P, Kumar K (2014) Vermiremediation of heavy metals in wastewater sludge from paper and pulp industry using earthworm Eisenia fetida. Ecotoxicol Environ Saf 109: 177-184.

Tognetti C, Laos F, Mazzarino MJ, Hernández MT (2005) Composting vs. vermicomposting: a comparison of end product quality. Compost Sci Util 13: 6-13.

Varma VS, Kalamdhad AS (2016) Efficiency of rotary drum composting for stabilizing vegetable waste during pre-composting and vermicomposting. Environ Process 3: 829-841.

Wei Y, Zhao Y, Zhao X, Gao X, Zheng Y, Zuo H, Wei Z (2020) Roles of different humin and heavy-metal resistant bacteria from composting on heavy metal removal. Bioresour Technol 296: 122375.

Yadav A, Garg VK (2019) Biotransformation of bakery industry sludge into valuable product using vermicomposting. Bioresour Technol 274: 512-517.

Zhang X, Lu Y, Shi Y, Chen C, Yang Z, Li Y, Feng, Y (2009) Antioxidant and metabolic responses induced by cadmium and pyrene in the earthworm Eisenia fetida in two different systems: contact and soil tests. Chem Ecol 25: 205-215.

Zhao S, Wang B, Zhong Z, Liu T, Liang T, Zhan J (2020) Contributions of enzymes and gut microbes to biotransformation of perfluorooctane sulfonamide in earthworms (Eisenia fetida). Chemosphere 238: 124619.

Zhu W, Yao W, Zhang Z, Wu Y (2014) Heavy metal behavior and dissolved organic matter (DOM) characterization of vermicomposted pig manure amended with rice straw. Environ Sci Pollut Res 21: 12684-12692. 